\title{
Optimal Parameters for in Vitro Development of the Fungus Hydrocarbonoclastic Penicillium sp.
}

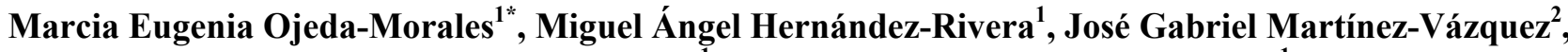 \\ Yolanda Córdova-Bautista ${ }^{1}$, Yuridia Evelin Hernández-Cardeño ${ }^{1}$ \\ ${ }^{1}$ División Académica de Ingeniería y Arquitectura, Universidad Juárez Autónoma de Tabasco, Cunduacán, México \\ ${ }^{2}$ Facultad de Salud y Ciencias A. F., Universidad SEK, Santiago, Chile \\ Email: ${ }^{*}$ marcy-ojeda@hotmail.com
}

Received July 18, 2013; revised August 18, 2013; accepted August 28, 2013

Copyright (C) 2013 Marcia Eugenia Ojeda-Morales et al. This is an open access article distributed under the Creative Commons Attribution License, which permits unrestricted use, distribution, and reproduction in any medium, provided the original work is properly cited.

\begin{abstract}
México has extensive areas that have been impacted by oil spills for several decades. Current bioremediation technologies mostly used microorganisms to decontaminate sites with hydrocarbons. This research evaluated the conditions for the optimal development of the strain of a hydrocarbonoclastic fungus, which was found in samples of soil contaminated with $4.0 \times 10^{5} \mathrm{mg} \cdot \mathrm{kg}^{-1}$ of Total Petroleum Hydrocarbons (TPH). A completely randomized experimental design with a $3 \times 3 \times 4$ factor arrangement was used: three levels of temperature $\left(\mathrm{T}_{1}=29^{\circ} \mathrm{C}, \mathrm{T}_{2}=35^{\circ} \mathrm{C}\right.$ and $\left.\mathrm{T}_{3}=40^{\circ} \mathrm{C}\right)$, three of $\mathrm{pH}\left(\mathrm{pH}_{1}=3.5, \mathrm{pH}_{2}=5.0\right.$ and $\left.\mathrm{pH}_{3}=6.0\right)$ and four nutrients $\left(\mathrm{N}_{1}=\right.$ Urea, $\mathrm{N}_{2}=$ Triple-17, $\mathrm{N}_{3}=$ Nitrophoska-Blue and $\mathrm{N}_{4}=$ Pure-Salts). Total fungi were isolated from the sampled soil and were sown in a combined carbon medium for hydrocarbonoclastic fungi and a strain was selected to be adapted to a liquid mineral medium. The selected strain was classified as Penicillium sp. Analyses of variance and mean tests were performed, using the SPSS-11.0 statistical software. The microorganisms showed the highest population growth in the treatment $\mathrm{N}_{2} \mathrm{pH}_{2} \mathrm{~T}_{1}$, which reached a value of $2.1 \times 10^{6} \mathrm{CFU} \cdot \mathrm{mL}^{-1}$ in a biorreactor. To reach it, by bioaugmentation, the same development of Penicillium sp. in a conditioned soil would allow to implement a bioremediation strategy with great potential to retrieve soil contaminated with hydrocarbons both in Tabasco and in general in Mexico.
\end{abstract}

Keywords: Hydrocarbon Degraders; Optimal Growth; Penicillium sp.; Hydrocarbonoclastic

\section{Introduction}

The exploitation of energy resources in the state of Tabasco is of great importance for Mexico [1]. The total amount of crude oil extraction in 2009 in Mexico was 2.6 million of daily barrels. $77.5 \%$ of these barrels were obtained from the Mexican Gulf [2], and the other 22.5\% were from wells in land. $77 \%$ of the petroleum extracted from the wells in land came from fields located in the state of Tabasco [3], which represented the $3.7 \%$ of the Gross National Product (GNP) [4]. However, oil industry accidents like rupture of pipelines and shipwrecks cause oil spills on land and marine ecosystems, producing pollution processes that affect the biophysical properties of soil and water and the biological components of these ecosystems. All this prevents the polluted natural resources from being fully exploited as well as health

${ }^{*}$ Corresponding author. problems to the population living there [5,6]. Several studies including bioremediation techniques have been carried out in these sites, to stop the problems affecting the ecology and human health.

Bioremediation uses the metabolic potential of microorganism to clean up an open polluted environment [7]. In the oil industry, it is becoming a widely used and cost effective technique to clean up hydrocarbons due to its simple use over large areas and its capacity to completely destroy the contaminant $[8,9]$. Within bioremediation, the bioaugmentation involves the inoculation of a strain or an enriched mixed microbial consortium in the soil [10-16]. It was found that indigenous microorganisms are especially efficient in the degradation of indigenous crude oil (produced in a determined region), but they are not that efficient in oils coming from other sites [17]. Native or indigenous microbes are present in small quantities and cannot prevent the contaminant from being 
spread; they do not have the capacity to degrade a particular contaminant or they can be in an inactive metabolic form in their habitats, which is why bioaugmentation is preferred over biostimulation [18]. Bioaugmentation offers an option to grow specific microbes in sufficient amounts to complete the biodegradation $[15,16,19]$. In this context, there exist a great number of heterotrophic microorganisms capable of using oil hydrocarbons as a source of carbon and energy, producing carbon dioxide, water, biomass and other less toxic products [20]. Among the group of fungi, the most extensive studies have focused on white rot fungi [21,22]. Filamentous fungi have some features that make them excellent agents of degradation. Once the microorganisms quickly ramify and the fungal hyphae penetrate the polluted soil, they reach the substratum and absorb it through the secretion of extracellular enzymes. They grow under stress conditions: under $\mathrm{pH}$, lack of nutrients and low water activity [23]. Fungi have also demonstrated their ability to degrade in some cases, such as mineralize phenols, halogenated phenolic compounds, petroleum hydrocarbons, polycyclic aromatic hydrocarbons and polychlorinated biphenyls in large stress conditions [24,25].

The Penicillium sp. fungi have been used in studies of crude oil biodegradation [16,23,25-28], and the mineralization of a variety of oil derivates, such as polycyclic aromatic hydrocarbons (PAHs), including pyrene, chrysene, and benzo [a] pyrene and polar metabolites [12,25, 29-31], as well as toxicity studies with hexadecane, phenanthrene and beta-naphthol, as biodegradation sometimes cannot be carried out because of the toxicity of the oil rather than its own persistence [9]. The metabolism of PAHs by strains of filamentous fungi is mediated by extracellular lignolytic enzymes or intracellular cytochrome P450 monooxygenases [32,33]. Both routes mainly produce quinones as oxidation products, which have higher solubility and reactivity than starting PAH [34-36]. In the case of the Penicillium fungi, the monooxygenase enzyme systems are responsible for degrading PAHs, where the first steps of oxidation are the formation of monophenols, diphenols, dihydrodiol and quinone [35]. In a second step, conjugates of O-methyl and sulfate can be formed; they are detoxification products soluble in water [37].

It has been reported that fungi are better than bacteria in the degradation of hydrocarbons in both quantity and variety of constituents, indicating that the species of fungi most commonly found in soil and seawater contaminated with hydrocarbons are the genera Aspergillus and Penicillium [9,16,38,39]. The ability of Aspergillus and Penicillium sp. to tolerate these pollutants and grow in them, suggests they may be used as bioremediation agents and can be used in the restoration of the ecosystem when impacted by these pollutants, because they produce enzymes and acids that break and dismantle the long chains of hydrocarbons, the base structure common to oils, petroleum products and many other pollutants [29]. Despite the abundance of fungi, Penicillium in particular has received little attention in studies of biodegradation, with a relatively small number of pilot projects and large-scale studies using this organism that has a high potential in the field of bioremediation [25].

The objective of this study was to evaluate the optimal physicochemical and nutrient conditions that promote higher biomass growth of a hydrocarbonoclastic strain of the Penicillium sp., in order to have new strategies that allow the use of this strain in bioremediation by bioaugmentation in soil contaminated with crude oil or petroleum products, both in the state of Tabasco and throughout Mexico.

\section{Material and Methods}

The research was conducted in two stages: the first consisted of three phases where the process of isolation, purification, testing, characterization, and preservation of hydrocarbonoclastic microorganisms was developed.

\subsection{Stage 1. Assessment, Characterization and Adaptation of Hydrocarbonoclastic Fungi.}

Samples from a Gleysol-mollic contaminated soil were collected in the facilities of an oil field located in the Huimanguillo municipality [40], state of Tabasco in Mexico, at an altitude of 20 meters above sea level [41]. Simple soil samples were taken, in accordance with the Mexican Official Standard 021 [42], for a total of 5000 $\mathrm{m}^{2}$ (0.5 ha), and stored at $4.0^{\circ} \mathrm{C}$ until use. Then, the Total Petroleum Hydrocarbons (TPH) present in the soil samples were determined by the method of extraction $[43,44]$, in their heavy fraction (greater than C18) and then quantified by gravimetry [45]. Soil samples were subjected to sowing in Phase I.

\subsubsection{Phase I}

The process of isolation, purification and preservation of total fungi was based on their growth and reproduction in the Potato Dextrose Agar growth medium PDA (Baker). Prepared according to the manufacturer, it was poured in petri dishes and sterilized. A solution was prepared with $10.0 \mathrm{~g}$ of the sampled soil in $90 \mathrm{~mL}$ of sterile distilled water, from which two serial dilutions were prepared: 1 $\mathrm{mL}$ of this solution was added to $9 \mathrm{~mL}$ of sterile distilled water $\left(10^{-1}\right)$, making and additional dilution, similar to the latter solution $\left(10^{-2}\right)$. Subsequently, $0.1 \mathrm{~mL}$ of the $10^{-1}$ dilution was sown in each of 6 the petri dishes with PDA, spreading with a Drigalsky spatula. The same was done with the $10^{-2}$ dilution and all of them were incubated at $28^{\circ} \mathrm{C}$ for 8 days (d). The quantification of total fungi was performed by the plate counts method for viable cells by serial dilution [46]. Selection tests of fungi 
in the soil were based on radial growth in the growth medium. Among the 24 strains of fungi found, 5 with the highest development were chosen to be assessed as hydrocarbonoclastic in Phase II (H14, H18, H19, H20 and H24). These strains were preserved on PDA medium in inclined tube at $4^{\circ} \mathrm{C}$ until use.

\subsubsection{Phase II}

Adaptation in Solid Medium Cellulose-Agar (SCA) for fungi to degrade total petroleum hydrocarbons. The SCA medium (Baker) was prepared according to Rivera-Cruz et al. [47], and poured into petri dishes. Culture media, Istmo crude oil with API index = 33.74 [48], in its heavy fraction (with molecules greater than C18) and the filter paper (squares with $1.5 \mathrm{~cm}$ on each side), were sterilized in wet heat during 20 minutes in autoclave at $121^{\circ} \mathrm{C}$ and $127,486 \mathrm{kPa}\left(1.3 \mathrm{kgf} \cdot \mathrm{cm}^{-2}\right)$ [48]. A $1.5 \times 1.5 \mathrm{~cm}$ filter paper impregnated with crude oil was placed on the SCA in the petri dishes under axenic conditions. On the other hand, the strains of fungi obtained from the previous phase were sown again. The mycelium of the preserved fungus colonies was touched with a handle and striated in the sterilized PDA medium prepared as indicated by the manufacturer. Then it was incubated at $35^{\circ} \mathrm{C}$ for $72 \mathrm{~h}$. For sowing in SAC, a slice of fungus with a reproductive structure of the sown strains was extracted with a puncher $(0.9 \mathrm{~cm}$ in diameter) and was placed on filter paper impregnated with oil, then the Petri dish was covered [40]. Sowing was done separately and in triplicate in the SCA medium for each fungal strain and incubated at $29^{\circ} \mathrm{C}$ for $6 \mathrm{~d}$, with evaluation every $24 \mathrm{~h}$. The three strains that showed more radial development, H14, H18 and $\mathrm{H} 24$ passed to the next phase.

\subsubsection{Phase III}

Adaptation of fungi in liquid mineral medium Cellulose-Agar (LCA) for fungi to degrade Total Petroleum Hydrocarbons (TPH). Fungi selected in Phase II were sown in the LCA medium. This was prepared as suggested by Rivera-Cruz [40], with crude oil incorporated into the culture medium as carbon and energy source. Then each organism was sown separately, as proposed by Rivera-Cruz et al. [47]. The fungal growth was determined every $72 \mathrm{~h}$ for $6 \mathrm{~d}$ and $\mathrm{H} 24$ strain was selected because of its higher population growth. A micro-culture of H24 in PDA was performed, and with the keys of Barnett and Hunter [49]. The organism was identified as Penicillium sp. This fungus was preserved in PDA medium at $4^{\circ} \mathrm{C}$ in inclined tube.

\subsection{Stage 2. Development of Experimental Design to Determine Optimal Growth Parameters}

The second stage was conducted in two phases. In the first phase an in vitro bioassay was established where the fungus selected in the previous stage was subjected to four nutrient media, varying $\mathrm{pH}$ and temperature. In the second phase a test of fungal biomass production was done in a bioreactor (Kettler jar) with the parameters that stimulated an optimal development of the microorganism.

\subsubsection{Phase I}

An in vitro bioassay was established, based on a completely randomized design in $3 \times 3 \times 4$ factorial type, namely: three levels of temperature $\left(\mathrm{T}_{1}=29^{\circ} \mathrm{C}, \mathrm{T}_{2}=\right.$ $35^{\circ} \mathrm{C}$ and $\left.\mathrm{T}_{3}=40^{\circ} \mathrm{C}\right)$, three $\mathrm{pH}$ levels $\left(\mathrm{pH}_{1}=3.5, \mathrm{pH}_{2}=\right.$ 5.0 and $\left.\mathrm{pH}_{3}=6.0\right)$ and four types of nutrients $\left(\mathrm{N}_{1}=\right.$ Urea, $\mathrm{N}_{2}=$ Triple-17, $\mathrm{N}_{3}=$ Nitrophoska-Blue and $\mathrm{N}_{4}=$ PureSalts), under the statistical model of Equiation (1).

$$
\mathrm{Y}_{\mathrm{ijk}}=\mu+\mathrm{T}_{\mathrm{i}}+\mathrm{N}_{\mathrm{j}}+\mathrm{pH}_{\mathrm{k}}+\mathrm{T}_{\mathrm{i}} \mathrm{N}_{\mathrm{j}}+\mathrm{T}_{\mathrm{i}} \mathrm{pH}_{\mathrm{k}}+\mathrm{N}_{\mathrm{i}} \mathrm{pH}_{\mathrm{j}}+\mathrm{E}_{\ell(\mathrm{ijk})}
$$

Temperatures of $35^{\circ} \mathrm{C}$ and $40^{\circ} \mathrm{C}$ were established using two glass trays, each connected to an electric heater. Water temperature was kept constant using a submersible recirculation pump. To determine nutrients and $\mathrm{pH}$ parameters, $250 \mathrm{~mL}$ Erlenmeyer flasks were used, divided into three series of 12 treatments; they were connected to a compressor with filter membrane and valve controller for supplying sterile air.

Preparation of culture media. Growth media used were: $\mathrm{N}_{1}=$ Urea (Abbot), $\mathrm{N}_{2}=$ Triple-17 NPK (Rancho Los Molinos), $\mathrm{N}_{3}=$ Nitrophoska-Blue 12-12-17-6 NPKS (Compo) and $\mathrm{N}_{4}=$ pure-Salts $\mathrm{Na}_{2} \mathrm{HPO}_{4}, \mathrm{KH}_{2} \mathrm{PO}_{4}, \mathrm{NH}_{4} \mathrm{Cl}$, $\mathrm{MgSO}_{4} \cdot 7 \mathrm{H}_{2} \mathrm{O}$ [50], prepared with equal proportions of $\mathrm{C}$, based on the same amount of glucose (Merck), added to each medium. The fertilizer nutrients had proportional relations in the following NPK elements: proportion between Pure-Salts: Triple-17, N (approx. 1:1), P (approx. 4:1), K (approx. 2:1), respectively; proportion between Triple-17:Nitrophoska-Blue, P (2.8:1), N (2.8:1), K (1:1); proportion between Urea:Pure-Salts, N (3.4:1). Moreover, the mass load was the same for the three organic fertilizers. Media were prepared as follows: for each of the four media, three Erlenmeyer flasks with $500 \mathrm{~mL}$ of distilled water (Mercury Chemical) and $2.5 \mathrm{~g}$ of glucose as carbon source were prepared. The first medium contained $0.25 \mathrm{~g}$ of Urea, the second: $0.25 \mathrm{~g}$ of Triple-17, the third, $0.25 \mathrm{~g}$ Nitrophoska-Blue and fourth: $0.5325 \mathrm{~g}$ of $\mathrm{Na}_{2} \mathrm{HPO}_{4}$ (Fermont), $0.325 \mathrm{~g}$ of $\mathrm{KH}_{2} \mathrm{PO}_{4}$ (Fermont), $0.125 \mathrm{~g}$ of $\mathrm{NH}_{4} \mathrm{Cl}$ (Golden Bell), $0.05 \mathrm{~g}$ of $\mathrm{MgSO}_{4} \cdot 7 \mathrm{H}_{2} \mathrm{O}$ (JT Baker), making a total of 12 flasks. Then, each of these nutrient media was adjusted in $\mathrm{pH}$ to $3.5,5.0$ and 6.0 respectively, using 0.1 $\mathrm{M}$ of $\mathrm{H}_{2} \mathrm{SO}_{4}$ (JT Baker) and $\mathrm{NaOH}$ (JT Baker) solutions. To assess the nutrient media at each temperature, $150 \mathrm{~mL}$ of each nutrient medium with its $\mathrm{pH}$ adjusted were measured in triplicate and placed in a 250 
$\mathrm{mL}$ flask, obtaining 36 experimental units (EU), according to experimental design. The EU were sterilized for 20 min at $121^{\circ} \mathrm{C}$ and $103,421 \mathrm{kPa}\left(15 \mathrm{lb}_{\mathrm{f}} \mathrm{plg}^{-2}\right)$. These EU were subsequently inoculated with Penicillium sp.

Preparation of inoculum: The Penicillium sp. Preserved (Phase III in Stage I) was re-isolated in Petri dishes on PDA medium prepared as indicated by the manufacturer, then it was sterilized; the mycelium of the fungus colonies preserved was touched with a handle and striated in the PDA medium. Then, it was incubated at $35^{\circ} \mathrm{C}$ for $72 \mathrm{~h}$. After that, the mycelium of the re-insulated fungus was touched with a handle and striated in the PDA medium in an inclined tube and incubated at $35^{\circ} \mathrm{C}$ for $4 \mathrm{~d}$. Then $5 \mathrm{~mL}$ of sterile distilled water was added in the inclined tube to allow separation of the spores. The above mixture was poured into an Erlenmeyer flask with $100 \mathrm{~mL}$ of water in axenic conditions. The initial spore concentration was determined in this volume by counting in a Neubauer chamber according to Pica et al. [51]. $2.5 \mathrm{~mL}$ of this inoculant medium was injected in each of the $36 \mathrm{EU}$ under axenic conditions to homogenize and the initial amount of inoculum Colony Forming Unit (CFU) of Penicillium sp. was determined at time zero hours $(t=0 \mathrm{~h})$. The evaluation of the Penicillium sp. growth in the EU was made every $2 \mathrm{~d}$ for $37 \mathrm{~d}$ by the method of counting viable cells by plating on surface [46]. Also, $\mathrm{pH}$ values and temperature were measured every $24 \mathrm{~h}$ during the time the experiment lasted.

\subsubsection{Phase II}

Production of fungal biomass in a bioreactor (Kettler jar). The production of biomass Penicillium sp. was done in a $2000 \mathrm{~mL}$ bioreactor fitted with a mechanical stirrer, sterile air inlet, sample taking, and air outlet to release pressure. The optimal parameters for microbial growth from the previous phase: $\mathrm{N}_{2}=$ Triple- $17, \mathrm{pH}_{2}=5.0, \mathrm{~T}_{1}=29^{\circ} \mathrm{C}$ were adjusted to prepare $1100 \mathrm{~mL}$ of nutrient medium that was sterilized in the bioreactor for $20 \mathrm{~min}$ at $121^{\circ} \mathrm{C}$ and $103,421 \mathrm{kPa}\left(15 \mathrm{lb}_{\mathrm{f}} / \mathrm{plg}^{2}\right)$, and $18.33 \mathrm{~mL}$ of inoculant prepared similarly to the previous phase was added. Then, it was shaken to homogenize and sampled to determine initial CFU number $(\mathrm{t}=0 \mathrm{~h})$. The evaluation of the development of Penicillium sp. was performed every $24 \mathrm{~h}$ for a period of $15 \mathrm{~d}$. In both cases the quantification of $\mathrm{CFU}$ of the microorganism is determined similarly to the previous phase. Temperature and $\mathrm{pH}$ were measured during each evaluation of fungal growth.

\section{Results}

The study was conducted on soil contaminated with Istmo crude oil (hydrocarbon chain greater than C18), with API $=33.74$ [48], in order to find and isolate hydrocarbonoclastic microorganisms to be used in the production of fungal biomass. It was determined that the soil was contaminated with $4.0 \times 10^{5} \mathrm{mg} \cdot \mathrm{kg}^{-1} \mathrm{HTP}(400,000$ $\mathrm{ppm}$ ). In the microbial isolation (Phase 1 of Stage 1), 24 strains of total fungi were found. Figure 1 shows the results for 14 strains of fungus. The 5 strains selected for further evaluation in Phase II were those with the highest radial development in the PDA culture medium.

Sowing the 5 strains of the previous Phase in Solid medium Cellulose-Agar (SCA) for TPH degrading fungi (Phase II) resulted in a greater development for strains H14, H18 and H24. These 3 strains passed to phase III (Table 1).

Table 2 (Phase III) shows the growth performance of the three selected fungi in Phase II in a mineral medium enriched with crude oil (LCA). Its speed behavior was observed over time (6 d). Likewise, it was verified that the crude oil surface tension cracked, completely chang-

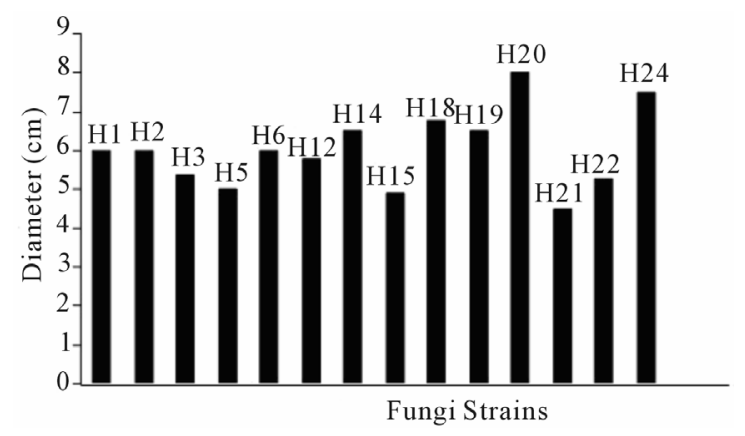

Figure 1. Radial growth of the fungi on PDA medium.

Table 1. Radial growth of fungal strains in Solid medium Cellulose-Agar (SCA) to TPH degrading fungi.

\begin{tabular}{ccccccc}
\hline Fungal Strain & \multicolumn{5}{c}{ Development radial $(\mathrm{cm})$ on each day $(\mathrm{d})$} \\
\hline $\mathrm{H} 14$ & $1 \mathrm{~d}$ & $2 \mathrm{~d}$ & $3 \mathrm{~d}$ & $4 \mathrm{~d}$ & $5 \mathrm{~d}$ & $6 \mathrm{~d}$ \\
$\mathrm{H} 18$ & 0.9 & 1.1 & 2.0 & 3.2 & 4.6 & 5.4 \\
$\mathrm{H} 19$ & 0.9 & 1.3 & 2.2 & 3.5 & 4.7 & 6.2 \\
$\mathrm{H} 20$ & 0.9 & 0.9 & 1.2 & 1.5 & 1.8 & 1.9 \\
$\mathrm{H} 24$ & 0.9 & 1.0 & 1.5 & 1.8 & 2.0 & 2.2 \\
\hline
\end{tabular}

Table 2. Growth of fungal strains as colony forming units (CFU) in Liquid mineral medium Cellulose-Agar (LCA), enriched with crude oil during the 6-d-long experiment.

\begin{tabular}{cccc}
\hline $\begin{array}{c}\text { Fungal } \\
\text { Strain }\end{array}$ & $\begin{array}{c}\text { CFU start } \\
\mathrm{t}=0 \mathrm{~h}\end{array}$ & CFU at $\mathrm{t}=72 \mathrm{~h}$ & $\begin{array}{c}\text { CFU at a } \\
\mathrm{t}=144 \mathrm{~h}\end{array}$ \\
\hline $\begin{array}{c}\text { Control } \\
\text { (without oil) }\end{array}$ & $3.0 \times 10^{-3}$ & $3.1 \times 10^{-3}$ & $2.8 \times 10^{-3}$ \\
$\mathrm{H} 14$ & $3.0 \times 10^{-3}$ & $2.8 \times 10^{-4}$ & $3.1 \times 10^{-5}$ \\
$\mathrm{H} 18$ & $3.0 \times 10^{-3}$ & $3.4 \times 10^{-4}$ & $5.2 \times 10^{-5}$ \\
$\mathrm{H} 24$ & $3.0 \times 10^{-3}$ & $7.2 \times 10^{-4}$ & $7.8 \times 10^{-4}$ \\
\hline
\end{tabular}


ing its appearance. With these results, the three strains of fungi were identified as hydrocarbonoclastic. From these strains, the one named H24 and identified as Penicillium sp. by comparison with the keys of Barnett and Hunter [49] had the largest growth during the period of the experiment and was selected for evaluation in Stage 2.

In assessing the growth of Penicillium sp. in a flask (Stage 2, Phase I), an increase in the viscosity of the medium during the biomass growth was observed. With the data obtained the mean test was done.

Figure 2 shows the results of treatments at different temperatures, nutrients and $\mathrm{pH}$. Figure 2(a) indicates that the growth of Penicillium sp. was the best at a temperature of $29^{\circ} \mathrm{C}$, but slightly less in the other two temperatures. Figure 2(b) indicates that the microorganism had a better development in the medium with Pure-Salts, but not very different from the media with NitrophoskaBlue and Triple-17. The lowest growth was in the medium with Urea. Figure 2(c) shows that the population growth of Penicillium sp. was higher at $\mathrm{pH} 3.5$ but not so different to that achieved in the other two $\mathrm{pH}$ values.

Figure 3 shows the results of the treatments that had the largest population growth of Penicillium sp. According to the experimental design. The amount of microorganisms to $\mathrm{t}=0 \mathrm{~h}$ was $4500 \mathrm{CFU} \cdot \mathrm{mL}^{-1}$. It was observed that the best results were obtained with the medium $\mathrm{N}_{4}=$ Pure-Salts, $\mathrm{pH}_{1}=3.5, \mathrm{~T}_{1}=29^{\circ} \mathrm{C}$, with a maximum population growth of $2.94 \times 10^{6} \mathrm{CFU} \cdot \mathrm{mL}^{-1}$ at $13 \mathrm{~d}$. The next best treatments were (in decreasing order of fungal growth $): \mathrm{N}_{2}=$ Triple-17, $\mathrm{pH}_{2}=5.0, \mathrm{~T}_{1}=29^{\circ} \mathrm{C}(2.06 \times$ $10^{6} \mathrm{CFU} \cdot \mathrm{mL}^{-1}$ at $\left.11 \mathrm{~d}\right), \mathrm{N}_{2}=$ Triple-17, $\mathrm{pH}_{1}=3.5, \mathrm{~T}_{1}=$ $29^{\circ} \mathrm{C}\left(1.50 \times 10^{5} \mathrm{CFU} \cdot \mathrm{mL}^{-1}\right.$ at $\left.25 \mathrm{~d}\right)$ and $\mathrm{N}_{2}=$ Triple- 17 ,
$\mathrm{pH}_{3}=6.0, \mathrm{~T}_{2}=35^{\circ} \mathrm{C}\left(2.85 \times 10^{6}\right.$ at $\left.20 \mathrm{~d}\right)$, respectively. The maximum multiplication of the media prepared with urea was $\mathrm{N}_{1}=$ Urea, $\mathrm{pH}_{1}=3.5, \mathrm{~T}_{1}=29^{\circ} \mathrm{C}\left(8.9 \times 10^{4}\right.$ $\mathrm{CFU} \cdot \mathrm{mL}^{-1}$ at $25 \mathrm{~d}$ ), being significantly lower compared to the previous ones.

The design for the production of fungal biomass from Penicillium sp. in the bioreactor (Phase II of Stage II) considered both, the best experimental treatment $\left(\mathrm{N}_{4} \mathrm{pH}_{1} \mathrm{~T}_{1}\right)$, and the most suitable organic media $\left(\mathrm{N}_{2} \mathrm{pH}_{2} \mathrm{~T}_{1}\right)$. The assessment of the population dynamics of the fungal strain in the bioreactor was performed in the selected medium $\mathrm{N}_{2}=$ Triple-17, $\mathrm{pH}_{2}=5.0, \mathrm{~T}_{1}=29^{\circ} \mathrm{C}$, because it proved to be the most favorable among all organic nutrient media and economically, the most suitable of all evaluated media for possible application to larger scales. Thus, in the medium $\mathrm{N}_{2} \mathrm{pH}_{2} \mathrm{~T}_{1}$ the exponential phase of fungal growth was observed between days 8 to 10 of culture, peaking on day 10 to $2.1 \times 10^{6} \mathrm{CFU} \cdot \mathrm{mL}^{-1}$, to minimally decrease later the cell number (Figure 4).

\section{Discussion}

The study was conducted in the state of Tabasco, Mexico on a Gleysol-mollic soil that has been contaminated for more than 20 years with crude oil [52]. A value of $4.0 \times$ $10^{5} \mathrm{mg} \cdot \mathrm{kg}^{-1} \mathrm{TPH}$ was found $(400,000 \mathrm{ppm}) .24$ strains of total fungi were obtained (Figure 1 shows the 14 strains with higher multiplication). The so-called H14, H18, H19, H29 and H24 had the highest population development in the PDA medium and then were sown in the SCA medium where colonies H14, H18 and H24 showed greater growth (Table 1). They could be considered, ac-

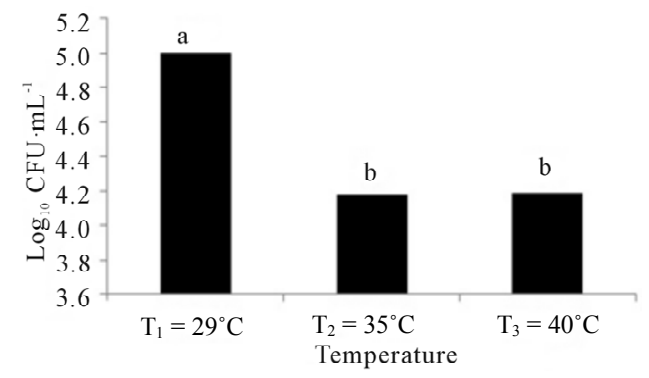

(a)

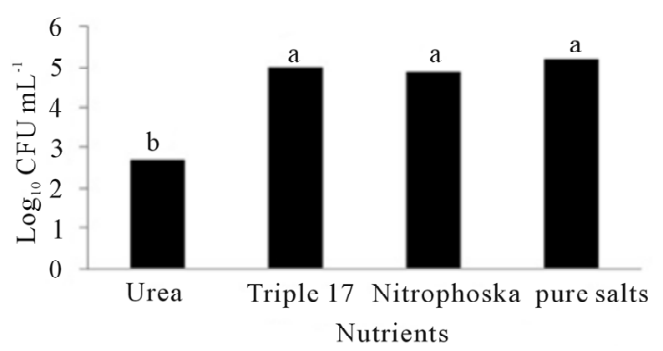

(b)

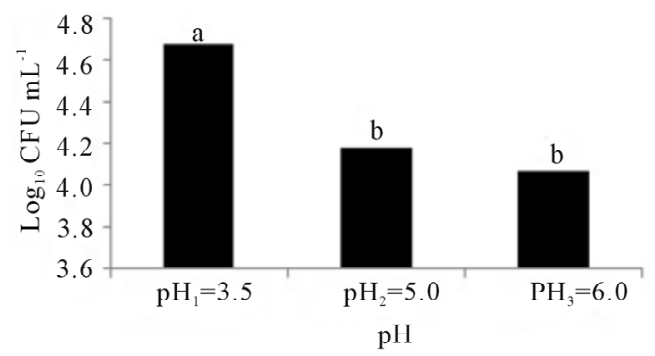

(c)

Figure 2. Growth of Penicillium sp. at different conditions of: (a) Temperature, (b) Nutrients and (c) pH. Treatment means with different letters are statistically significant differences $(\alpha \leq 0.05)$. 


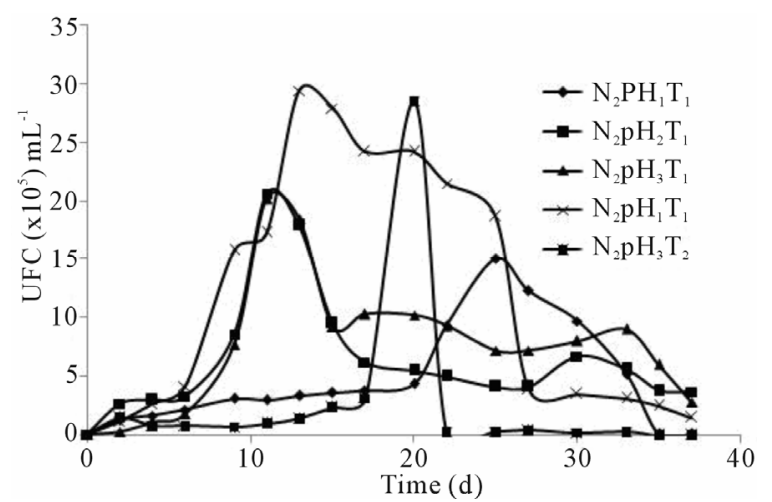

Figure 3. Growth of Penicillium sp. on flask treatments (4.5 $\times 10^{3} \mathrm{CFU} \cdot \mathrm{mL}^{-1}$, to $\mathrm{t}=\mathbf{0} \mathrm{d}$ ).

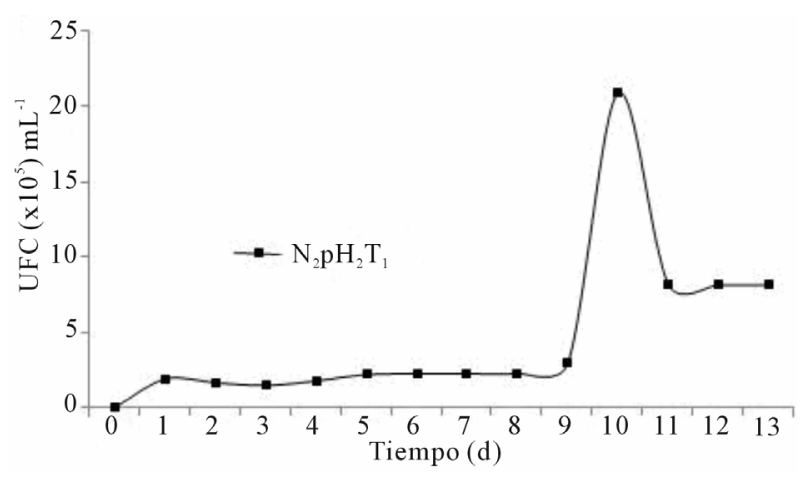

Figure 4. Growth of Penicillium sp. on bioreactor treatment $\left(4.2 \times 10^{3} \mathrm{CFU} \cdot \mathrm{mL}^{-1}\right.$, to $\left.\mathrm{t}=0 \mathrm{~d}\right)$.

cording to Atlas et al. [53] and Adams-Schroeder et al. [54], as specialized degrading hydrocarbons strains, because of their ability to adapt in soils with high concentrations of crude oil and use it as a source of carbon and energy due to their genetic potential $[16,25,46,55,56]$. Subsequently, these 3 strains were sown in the LCA medium, where $\mathrm{H} 24$ had the highest population growth (Table 2), and was classified as Penicillium sp. based on macro and microscopic characteristics [49,57-59].

These findings were consistent with those found in other countries with oil industry, since the Penicillium fungi have been found in soils in kwait [60], Canada [61], Africa [16,17,29,62], Chile [39] and Korea [63], among others. Even in studies of agricultural soils in their natural state, it was found that native Penicillium sp. survived and degraded hydrocarbons when it was added crude oil, without having previously been in contact with the pollutant [28]. Likewise, when Penicillium sp. from feces of cattle and poultry was added on contaminated soil it survived and degraded crude oil, although just participating in fungal consortia [64]. Several studies have indicated that the Penicillium sp. degraded crude oil, using it as its sole source of carbon and energy [16,23,25,26,28,64-66], or oil derivates with the same purpose $[9,25,29,31,63]$. This can be attributed to the fact that Penicillium sp. has in its membrane a specific group of oxygenases associated with the production of surface-active agents [67,68], which reduce the surface tension of the aqueous medium increasing the TPH solubility [69]. In this regard, we can only discuss so far the potential of Penicillium in the field of bioremediation, since large-scale studies have not been reported [25]. Nor information is available on fungal biomass generation of this hydrocarbonoclastic fungus and its application in bioremediation of crude oil in soils.

Afterward, the experiment was carried out in laboratory to determine the optimal parameters of fungal growth. The Penicillium sp. showed red pigmentation in the treatments with Urea. Mendez-Zavala et al. [70], noted a similar color with Penicillium purpurogenum. This might be because the Urea treatments contained a greater concentration of nitrogen. Cho et al. [71] reported that the nitrogen source marks a very significant effect on the expression of pigments as well as the presence of sucrose and starch [72]. Alexander [73] indicated that the organisms have optimal growth in a temperature range of $28^{\circ} \mathrm{C}$ to $30^{\circ} \mathrm{C}$, although Saraswathy et al. [74], used $22^{\circ} \mathrm{C}$ in their studies with Penicillium ochrochloron. Several researchers have reported $30^{\circ} \mathrm{C}$ or $31^{\circ} \mathrm{C}$ as optimal temperatures for development of Penicillium sp. $[9,23,25,26]$. Corry [75] and Lacey [76] have also reported that nine species of Penicillium have an average temperature of $28^{\circ} \mathrm{C}$ for optimum growth. Figure 2(a) shows that Penicillium sp. had the best population growth at a temperature of $29^{\circ} \mathrm{C}$ (Tukey $\alpha \leq 0.05$ ), which agrees with Isitua and Ibeh [29], who have recommended an interval of $28^{\circ} \mathrm{C} \pm 2{ }^{\circ} \mathrm{C}$ for the optimum growth of Penicillium sp. With regard to nutrients, significant statistical evidence (Figure 2(b)) supports the fact that the best growth was given in the Pure-Salts treatment $\left(1.6 \times 10^{5} \mathrm{CFU} \cdot \mathrm{mL}^{-1}\right)$; a reason could be that it contains $\mathrm{N}, \mathrm{P}$ and $\mathrm{K}$ and other trace elements. According to what Ercoli et al. report [77], the source of trace elements helps to improve the process of biodegradation of hydrocarbons. NitrophoskaBlue, Triple-17 and Urea fertilizers do not contain these bioelements. Figure 2(c) shows a statistically significant difference (Tukey $\alpha \leq 0.05$ ), with the largest population of $1 \times 10^{5} \mathrm{CFU} \cdot \mathrm{mL}^{-1}$ in the treatment $\mathrm{pH}_{1}=3.5$. According to Alexander [73], fungi have optimum growth in agar medium with a $\mathrm{pH}$ of 4.0 approximately. The results obtained by Sanchis et al. [78], in a study of Penicillium griseofulvum indicated that the optimum $\mathrm{pH}$ is reached in a range of 3.5 to 4.5 . Once with these data, the experimental design was outlined to determine the best conditions for Penicillium sp. growth, and so use the most efficient treatment in obtaining hydrocarbonoclastic fungal biomass.

Figure 3 shows the fungal growth obtained in the 5 best treatments of the experimental design. All media had 
a rapid microbial growth the first two days, and then continue their multiplication in the same order of magnitude gradually, prior to exponential growth. The treatment that achieved the highest multiplication of Penicillium sp. was the one formulated with Pure Salts $\mathrm{N}_{4} \mathrm{pH}_{1} \mathrm{~T}_{1}$, while the best organic media were those prepared with the Triple-17 fertilizer, and among them, the most efficient was $\mathrm{N}_{2} \mathrm{pH}_{2} \mathrm{~T}_{1}$ with a gradual growth of the microorganism to $4.2 \times 10^{5} \mathrm{CFU} \cdot \mathrm{mL}^{-1}$ on day 6 . Then it multiplied exponentially to reach $2.06 \times 10^{6} \mathrm{CFU} \cdot \mathrm{mL}^{-1}$ at 11 $\mathrm{d}$, decreased to $6.2 \times 10^{5} \mathrm{CFU} \cdot \mathrm{mL}^{-1}$ at day 17 and then it maintained a plateau with little variation in fungal concentration, to reach $3.7 \times 10^{5}$ at the end of the experiment (37 d). On the other hand, the medium $\mathrm{N}_{2} \mathrm{pH}_{3} \mathrm{~T}_{2}$ had a long multiplication time until day $17\left(3.0 \times 10^{5}\right.$ $\left.\mathrm{CFU} \cdot \mathrm{mL}^{-1}\right)$, reaching the maximum exponential growth on day 20 with $2.85 \times 10^{6} \mathrm{CFU} \cdot \mathrm{mL}^{-1}$ and then it decreased sharply to $3.0 \times 10^{4}$ on day 22 and maintained a plateau with little change until day $33\left(3.0 \times 10^{4}\right.$ $\mathrm{CFU} \cdot \mathrm{mL}^{-1}$ ). The medium $\mathrm{N}_{2} \mathrm{pH}_{1} \mathrm{~T}_{1}$ had a gradual growth of $1.3 \times 10^{5}$ to $3.8 \times 10^{5} \mathrm{CFU} \cdot \mathrm{mL}^{-1}$ from day 2 to 17 , and then an exponential growth reaching a maximum concentration at day 25 with $1.5 \times 10^{6} \mathrm{CFU} \cdot \mathrm{mL}^{-1}$; then it decreased to $1.0 \times 10^{4} \mathrm{CFU} \cdot \mathrm{mL}^{-1}$ at $37 \mathrm{~d}$ without forming a plateau. Moreover, the development of the fungus in the medium $\mathrm{N}_{1} \mathrm{pH}_{1} \mathrm{~T}_{1}$ remained in the same order of magnitude, with 1.5 to $2.9 \times 10^{4} \mathrm{CFU} \cdot \mathrm{mL}^{-1}$ from 2 to 17 , then increased to a maximum population of $8.9 \times 10^{4}$ $\mathrm{CFU} \cdot \mathrm{mL}^{-1}$ to day 25 and then decreased to $1.4 \times 10^{4}$ $\mathrm{CFU} \cdot \mathrm{mL}^{-1}$ at day 33. $\mathrm{N}_{2} \mathrm{pH}_{2} \mathrm{~T}_{1}$ treatment reached a maximum population development $27.7 \%$ less than the one obtained by the $\mathrm{N}_{2} \mathrm{pH}_{3} \mathrm{~T}_{2}$, but the first was achieved significantly faster ( $11 \mathrm{~d}$ and $20 \mathrm{~d}$, respectively).

Comparing treatments $\mathrm{N}_{2} \mathrm{pH}_{2} \mathrm{~T}_{1}$ and $\mathrm{N}_{2} \mathrm{pH}_{1} \mathrm{~T}_{1}$, the second had a maximum population growth of $7.3 \%$ of the first, while treatment $\mathrm{N}_{1} \mathrm{pH}_{1} \mathrm{~T}_{1}$ had a multiplication of only $4.3 \%$ compared to $\mathrm{N}_{2} \mathrm{pH}_{2} \mathrm{~T}_{1}$; also the times to reach maximum microbial development was considerably lower for the $\mathrm{N}_{2} \mathrm{pH}_{2} \mathrm{~T}_{1}$. The experimental conditions of $\mathrm{N}_{2} \mathrm{pH}_{2} \mathrm{~T}_{1}$ treatment are closely related to the $\mathrm{pH}$ and temperature values found as optimal in the literature as described above. It also provides the shortest adaptation time of Penicillium sp. and reaches a plateau of considerable concentration of microorganisms for a long time after the maximum fungal multiplication. The lowest microorganism reproduction was observed in media with urea. Likewise, the cost in Mexico (50 kg package, in U.S. Dollar) for each fertilizer used in this study was as follows: Urea \$21.34, Triple-17 \$25.77, NitrophoskaBlue \$61.04, and for Pure Salts: $\mathrm{Na}_{2} \mathrm{HPO}_{4} \$ 24.15$ (250 g), $\left.\begin{array}{lllllll}\mathrm{KH}_{2} \mathrm{PO}_{4} & \$ 28.66 & (250 & \mathrm{g}\end{array}\right), \quad \mathrm{NH}_{4} \mathrm{Cl} \quad \$ 48.31 \quad(500 \mathrm{~g})$, $\mathrm{MgSO}_{4} \cdot 7 \mathrm{H}_{2} \mathrm{O} \$ 44.28$ (500 g).

Based on the above, we chose the medium $\mathrm{N}_{2} \mathrm{pH}_{2} \mathrm{~T}_{1}$ to obtain fungal biomass in the bioreactor, with the additional consideration that Triple-17 fertilizer compared to
Nitrophoska-Blue has a higher proportion of $\mathrm{N}$ and $\mathrm{P}$ and an equal proportion of $\mathrm{K}$ (in addition to a better fungal growth). Besides, it is cheaper than Nitrophoska-Blue and the medium prepared with Pure Salts. Triple-17 was considered better than Urea because of its highest multiplication of Penicillium sp. and the high proportion of NPK nutrients that it has, although it was slightly more expensive than Urea.

The evaluation of the multiplication of Penicillium sp. in the bioreactor was carried out only after completing the stage of maximum microbial growth and the beginning of the decrease in concentration of fungi because there was an interest in obtaining the maximum fungal biomass. Comparing the results obtained with the flask and those obtained in the bioreactor about the growth assessment of the hydrocarbonoclastic fungus Penicillium sp. in the selected medium $\mathrm{N}_{2} \mathrm{pH}_{2} \mathrm{~T}_{1}$ prepared with Triple-17 (Figures 3 and 4), it was found that in a bioreactor a maximum fungal proliferation of $2.1 \times 10^{6}$ was obtained at day 10 , which means an increase of $2 \%$ in the $\mathrm{CFU} \cdot \mathrm{mL}^{-1}$ of the organism with respect to the experiment in the flask, decreasing thereafter to $8.17 \times 10^{5}$ at day 13. It was noted that the growth curve in both cases (flask and bioreactor) was not exactly the same, although very similar in behavior, with reduced time to obtain maximum fungal population from 11 to $10 \mathrm{~d}$ in the bioreactor. That could be due to greater efficiency in managing and controlling the aeration of the medium during the duration of the experiment in contrast to the study in the flask. The concentration of microorganisms reached in the bioreactor was high enough to be considered for possible inoculation of soil in bioremediation projects, compared to data published by Rivera-Cruz [40], who found low values like $10^{3} \mathrm{CFU}$ of fungi in the rhizosphere of German grass (Echinochloa polistachya) in Gleysol soil contaminated with crude oil.

\section{Conclusion}

It was determined that a Gleysol-mollic soil, in the state of Tabasco, México, with over 20 years of being impacted by crude oil, was contaminated with $4.0 \times 10^{5}$ $\mathrm{mg} \cdot \mathrm{kg}^{-1}$ (400,000 ppm) of TPH. From this soil, the hydrocarbonoclastic fungus Penicillium sp. was isolated and characterized. This organism was adapted to various conditions of temperature, $\mathrm{pH}$ and four nutrient media. Considering the variables listed in the experimental design and costs of the materials used to prepare the nutrient media, it was found that the treatment at a temperature of $29^{\circ} \mathrm{C}, \mathrm{pH} 5.0$, and nutrient media Triple- 17 $\left(\mathrm{N}_{2} \mathrm{pH}_{2} \mathrm{~T}_{1}\right)$ had the highest population growth at $11 \mathrm{~d}$ with $2.06 \times 10^{6} \mathrm{CFU} \cdot \mathrm{mL}^{-1}$. Subsequently, the experiment was performed in a bioreactor for the production of fungal hydrocarbonoclastic biomass, and it was found that the proliferation of Penicillium sp. was obtained at $10 \mathrm{~d}$ 
with $2.1 \times 10^{6} \mathrm{CFU} \cdot \mathrm{mL}^{-1}$. If this development could be achieved in contaminated soils with the proper soil preparation and bioaugmentation techniques, it would be considered a potential bioremediation strategy for solving the problem of hydrocarbon-contaminated soils in Tabasco in particular and in general in Mexico.

\section{Acknowledgements}

This research is part of the POA-2008011 project, "Determining of the optimal parameters to produce Fungal and Bacterial hydrocarbonoclastic Biomass" developed by the División Académica de Ingeniería y Arquitectura (DAIA) of the Universidad Juárez Autónoma de Tabasco (UJAT). It receives partial funding by the company Corporativo de Servicios Ambientales S. A. de C. V. (CORSA). The authors thank the DAIA/UJAT for all the support to carry out this research, to Ing. Alfredo Castro Betancourt, General Manager of CORSA S. A. de C. V. for all the procedures he went through to obtain finance for this project, to Mr. Alex Figueroa Munóz and Eva Flandes Aguilera, Dean of the Facultad de Salud y Ciencias A. F. and academic vice-rector, respectively, of the Universidad SEK, for their support in the organization and conclusion of this document.

\section{REFERENCES}

[1] INEGI, “Comunicado Núm. 203/09,” INEGI, 2009.

[2] N. Cruz-Serrano, "Pemex, tercera petrolera en el mundo en 2009," El Universal, 2013. http://www.eluniversal.com.mx/finanzas/80420.html

[3] E. C. Hernández, "Innovación Tecnológica Base Para Extracción de Petróleo,” Milenio Tabasco, 2013. http://www.skyscrapercity.com/showthread.php?t=63460 7 \&page $=18$

[4] S. Arias, "Desarrollo Económico de Tabasco," Tabasco hoy, 2013.

http://www.tabascohoy.com.mx/noticia.php?id_nota=190 648

[5] M. Levin and M. Gealt, "Biotratamiento de Residuos Tóxicos y Peligrosos,” McGraw-Hill. Madrid, 1997.

[6] J. Eweis, S. Ergas, D. Chag and E. Schoroeder, "Principios de Biorrecuperación,” McGraw-Hill, Madrid, 1999.

[7] K. Watanabe, "Microorganisms Relevant to Bioremediation," Current Opinion in Biotechnology, Vol. 12, No. 3, 2001, pp. 237-241.

http://dx.doi.org/10.1016/S0958-1669(00)00205-6

[8] W. T. Jr. Frankenberger, "The Need for a Laboratory Feasibility Study in Bioremediation of Petroleum Hydrocarbons," In: E. J. Calabrese andP. T. Kostecki, Eds., Hydrocarbon Contaminated Soils and Groundwater, Lewis Publication, Boca Raton, 1992, pp. 237-293.

[9] Y. Castro-Riquelme, "Estudios de Toxicidad y Biodegradacion de Hidrocarburos Modelo en Hongos Filamentosos," Maestría en Biotecnología Dissertation. Uni- versidad Autónoma Metropolitana, México, D.F., 2008.

[10] M. V. Walter, "Bioaugmentation," In: C. J. Hurst, Ed., Manual of Environmental Microbiology, ASM Press, Washington DC, 1997, pp. 753-765.

[11] R. M. Atlas and R. Unterman, "Bioremediation," In: A. L. Demain and J. E. Davies, Eds., Manual of Industrial Microbiology and Biotechnology, 2nd Edition, ASM Press, Washington DC, 1999, pp. 666-681.

[12] S. Boonchan, M. L. Britz and G. A. Stanley, "Degradation and Mineralization of High-Molecular-Weight Polycyclic Aromatic Hydrocarbons by Defined FungalBacterial Cocultures," Applied and Environmental Microbiology, Vol. 66, No. 3, 2000, pp. 1007-1019. http://dx.doi.org/10.1128/AEM.66.3.1007-1019.2000

[13] S. Barathi and N. Vasudevan, "Utilization of Petroleum Hydrocarbons by Pseudomonas fluorescens Isolated from a Petroleum-Contaminated Soil," Environment International, Vol. 26, No. 5-6, 2001, pp. 413-416. http://dx.doi.org/10.1016/S0160-4120(01)00021-6

[14] E. Seklemova, A. Pavlova and K. Kovacheva, "Biostimulation Based Bioremediation of Diesel Fuel: Field Demonstration," Biodegradation, Vol. 12, No. 5, 2001, pp. 311-316. http://dx.doi.org/10.1023/A:1014356223118

[15] I. Kuiper, E. L. Lagendijk, G. O. Bloemberg and B. J. J. Lugtenberg, "Rhizoremediation. A Beneficial Plant Microbe Interaction," Molecular Plant-Microbe Interactions, Vol. 17, No. 1, 2004, pp. 6-15. http://dx.doi.org/10.1094/MPMI.2004.17.1.6

[16] T. E. Ogbulie, H. C. Nwigwe, M. O. E. Iwuala and G. C. Okpokwasili, "Study on the Use of Monoculture and Multispecies on Bioaugumentation of Crude Oil Contaminated Agricultural Soil," Nigerian Journal of Microbiology, Vol. 24, 2010, pp. 2160-2167.

[17] A. F. Gesinde, E. B. Agbo, M. O. Agho and E. F. C. Dike, "Bioremediation of Some Nigerian and Arabian Crude Oils by Fungal Isolates," International Journal of Pure and Applied Sciences, Vol. 2, No. 3, 2008, pp. 37-44.

[18] A. D'Annibale, F. Rosetto, V. Leonardi, F. Federici and M. Petruccioli, "Role of Autochthonous Filamentous Fungi in Bioremediation of a Soil Historically Contaminated with Aromatic Hydrocarbons," Applied and Environmental Microbiology, Vol. 72, No. 1, 2006, pp. 28-36. http://dx.doi.org/10.1128/AEM.72.1.28-36.2006

[19] Conestoga-Rovers \& Associates (CRA), "Bioaugmentation," Innovative Technology Group, Vol. 3, No. 4, 2003, pp. 1-2.

[20] J. B. Davis, "Petroleum Microbiology," Elsevier, Amsterdam, 1967.

[21] J. A. Bumpus, "Biodegradation of Polycyclic Aromatic Hydrocarbons by Phanerochaete chrysosporium," Applied and Environmental Microbiology, Vol. 55, No. 1, 1989, pp. 154-158.

[22] T. S. Brodkorb and R. L. Legge, "Enhanced Biodegradation of Phenanthrene in Oil Tar-Contaminated Soils Supplemented with Phanerochaete chrysosporium," Applied and Environmental Microbiology, Vol. 58, No. 9, 1992, pp. 3117-3121.

[23] J. L. Solórzano-Lemos, A. C. Rizzo, V. S. Millioli, A. U. 
Soriano, M. I. De Moura-Sarquis and R. Santos, "Petroleum Degradation by Filamentous Fungi," Contribuição Técnica a 9th International Petroleum Environmental Conference, Novo México, 2002, pp. 21-25.

[24] H. Sing, "Mycoremediation," John Wiley \& Sons, Inc., Hoboken, 2006. http://dx.doi.org/10.1002/0470050594

[25] A. L. Leitão, "Potential of Penicillium Species in the Bioremediation Field," International Journal of Environmental Research and Public Health, Vol. 6, No. 4, 2009, pp. 1393-1417. http://dx.doi.org/10.3390/ijerph6041393

[26] H. M. Hussein and Y. R. Abdel-Fattah, "Numerical Modelling of Petroleum Oil Bioremediation by a Local Penicillium Isolate as Affected with Culture Conditions: Application of Plackett-Burman Design," Arab Journal of Biotechnology, Vol. 5, No. 2, 2002, pp. 165-172.

[27] A. Mittal and P. Singh, "Studies on Biodegradation of Crude Oil by Aspergillus niger," The South Pacific Journal of Natural and Applied Sciences, Vol. 27, No. 1, 2009, pp. 57-60.

[28] O. Obire and E. C. Anyanwu, "Impact of Various Concentrations of Crude Oil on Fungal Populations of Soil," International Journal of Environmental Science and Technology, Vol. 6, No. 2, 2009, pp. 211-218.

[29] C. C. Isitua and I. N. Ibeh, "Comparative Study of Aspergillus niger and Penicillium sp. in the Biodegradation of Automotive Gas Oil (AGO) and Premium Motor Spirit (PMS)," African Journal of Biotechnology, Vol. 9, 2010, pp. 3607-3610.

[30] E. Kiehlmann, L. Pinto and M. Moore, "The Transformation of Chrysene to Trans-1,2-dihydroxy-1,2-dihydrochrysene by Filamentous Fungi," Canadian Journal of Microbiology, Vol. 42, 1996, pp. 604-608. http://dx.doi.org/10.1139/m96-081

[31] C. Machín-Ramírez, D. Morales, F. Martínez-Morales, A. I. Okoh and M. R. Trejo-Hernández, "Benzo[a]pyrene removal by Axenic- and Co-Cultures of Some Bacterial and Fungal Strains," International Biodeterioration and Biodegradation, Vol. 64, No. 7, 2010, pp. 538-544. http://dx.doi.org/10.1016/j.ibiod.2010.05.006

[32] H. J. Van den Brink, R. F. M. van Gorcom, C. A. M. J. J. van den Hondel and P. J. Punt, "Cytochrome P450 Enzyme Systems in Fungi," Fungal Genetics and Biology, Vol. 23, No. 1, 1998, pp. 1-17. http://dx.doi.org/10.1006/fgbi.1997.1021

[33] C. E. Cerniglia and J. B. Sutherland, "Bioremediation of Polycyclic Aromatic Hydrocarbons by Ligninolytic Fungi," In: G. M. Gadd, Ed., Fungi in Bioremediation, Cambridge University Press, Cambridge, 2001, pp. 136-187. http://dx.doi.org/10.1017/CBO9780511541780.008

[34] J. A. Field, E. Jong, G. F. Cost and J. A. M. Bont, "Biodegradation of Polycyclic Aromatic Hydrocarbons by New Isolates of White Rot Fungi," Applied and Environmental Microbiology, Vol. 58, No. 7, 1992, pp. 22192226.

[35] L. Launen, L. Pinto, C. Wiebe, E. Kiehlmann and M. Moore, "The Oxidation of Pyrene and Benzo[a]pyrene by nonbasidiomycete Soil Fungi," Canadian Journal of Microbiology, Vol. 41, No. 6, 1995, pp. 477-488.

http://dx.doi.org/10.1139/m95-064
[36] L. Launen, L. Pinto and M. Moore, "Optimization of Pyrene Oxidation by Penicillium janthinellum Using Response-Surface Methodology," Applied Microbiology and Biotechnology, Vol. 51, No. 4, 1999, pp. 510-515. http://dx.doi.org/10.1007/s002530051425

[37] T. Wunder, J. Marr, S. Kremer, O. Sterner and H. Anke, "1-Methoxypyrene and 1,6-Dimethoxypyrene: Two Novel Metabolites in Fungal Metabolism of Polycyclic Aromatic Hydrocarbons," Archives of Microbiology, Vol. 167, 1997, No. 5, pp. 310-316. http://dx.doi.org/10.1007/s002030050449

[38] B. Chávez-Gómez, R. Quintero, F. Esparza-García, A. M. Mesta-Howard, D. F. J. Zavala, C. H. HernándezRodríguez, T. Gillén, H. M. Poggi-Varaldo, J. BarreraCortés and R. Rodríguez-Vázquez, "Removal of Phenanthrene from Soil by Co-Cultures of Bacteria and Fungi Pregrown on Sugarcane Bagasse Pith," Bioresource Technology, Vol. 89, No. 2, 2003, pp. 177-183. http://dx.doi.org/10.1016/S0960-8524(03)00037-3

[39] F. E. Valenzuela, M. L. Solís, V. O. Martínez and T. D. Pinochet, "Hongos Aislados Desde Suelos Contaminados Con Petróleo," Boletín Micológico, Vol. 21, 2006, pp. 35-41.

[40] M. C. Rivera-Cruz, "Microorganismos Rizosféricos de Los Pastos Alemán (Echinochloa polystachya H.B.K. Hitchc) y Cabezón (Paspahum virgatum L.) en la Degradación Del Petróleo Crudo y el Benzo(a)pireno," Ph.D. Dissertation, Colegio de Postgraduados, Montecillo, 2001.

[41] INEGI, "Síntesis Geográfica, Nomenclátor y Anexo Cartográfico del Estado de Tabasco," Instituto Nacional de Estadística y Geografía, Aguascalientes, 2001.

[42] SEMARNAT, "Norma Oficial Mexicana NOM-021RECNAT-2000. Apartado 6.1. Evaluación de la Conformidad Para Muestreo de Suelos. Muestreo Para Determinar Fertilidad de Suelos," Diario Oficial de la Federación, 2nd. Secc., México D.F., 2002.

[43] USEPA, "EPA-Method-3540C. Soxhlet Extraction. Hidrocarburos Totales Del Petróleo (Fracción Pesada)," 1996.

http://www.epa.gov/wastes/hazard/testmethods/sw846/pd fs/3540c.pdf

[44] USEPA, "EPA-Method-9071B. n-Hexane Extractable Material (hem) for Sludge, Sediment, and Solid Samples," 1998.

http://www.caslab.com/EPA-Methods/PDF/EPA-Method -9071B.pdf

[45] USEPA, "EPA-Method-1664A. Revition A. n-Hexane Extractable Material," 1999.

http://www.epa.gov/waterscience/methods/method/oil/16 64guide.pdf

[46] M. T. Madigan, J. M. Martinko, P. V. Dunlap and D. P. Clark, "Biología de Los Microorganismos," Pearson, Addison Wesley, Madrid, 2009.

[47] M. C. Rivera-Cruz, R. Ferrera-Cerrato, R. RodríguezVásquez and L. Fernández-Linares, "Adaptación y Selección de Microorganismos Autóctonos en Médios de Cultivos Enriquecidos Com Petróleo Crudo," Terra Latinoamericana, Vol. 20, No. 4, 2002, pp. 423-444. 
[48] H. Corvantes, "PEMEX: El Petróleo," Petróleos Mexicanos, 1988.

[49] H. Barnett and B. Hunter, "Illustrated Genera of Imperfect Fungi,” Burgess Pub. Company, Minnesota, 1972.

[50] M. Kästner, M. Breuer-Jammali and B. Mhro, "Enumeration and Characterization of the Soil Sites to Mineralize Polycyclie Aromatic Hidrocarbons," Applied Microbiology and Biotechnology, Vol. 41, No. 2, 1994, pp. 267273. http://dx.doi.org/10.1007/BF00186971

[51] G. Y. Pica, A. Ronco and B. M. Díaz, "Bioensayo de Toxicidad Crónica con Selenastrum capricornutum (Pseudokirchneriella subcapitata). Método de Enumeración Celular Basado en el Uso de Hematocímetro Neubauer," In: M. G. Castillo, Ed., Ensayos Toxicológicos y Métodos de Evaluación de Calidad de Aguas, Estandarización, intercalibración, Resultados y Aplicaciones, Instituto Mexicano de Tecnología del Agua, 2004, pp. 62-73.

[52] J. Zavala-Cruz, V. A. Botello, S. R. H. Adams and A. Ruiz-Bello, "Hidrocarburos Alifáticos y Aromáticos en las Tierras," In: J. Zavala-Cruz, M. C. GutiérrezCastorena and D. J. Palma-López, Eds., Impacto Ambiental en Las Tierras Del Campo Petrolero Samaria, Colegio de Postgraduados, CONACYT, CCYTET, Villahermosa, Tabasco, 2003, pp. 131-140.

[53] M. R. Atlas, A. Horowitz, M. Krichevky and K. A. Bej, "Response of Microbial Population to Environmental Disturbance," Microbial Ecology, Vol. 22, No. 1, 1991, pp. 249-256. http://dx.doi.org/10.1007/BF02540227

[54] R. H. Adams-Schroeder, V. I. Domínguez-Rodríguez and L. Vinalay-Carrillo, "Evaluation of Microbial Respiration and Ecotoxicity in Contaminated Soils Representative of the Petroleum Producing Region of Southeastern México," Terra, Vol. 20, No. 3, 2002, pp. 253-265.

[55] C. E. Cerniglia and M. A. Heitkamp, "Microbial Degradation of Polycyclic Aromatic Hydrocarbon (PAH) in the Aquatic Environment," In: U. Varausi, Ed., Metabolism of PAH in the Aquatic Environment, CRC Press Inc., Boca Raton, 1987, pp. 41-68.

[56] J. E. Heidelberg, I. I. Paulsen, K. E. Nelson, E. J. Gaidos, W. C. Nelson, T. D. Read and J. A. Eison, "Genome Sequence of the Dissimilatory Metal Ion-Reducing Bacterium. Shewanella oneidensis," Nature and Biotechnology, Vol. 1, 2002, pp. 1-6.

[57] J. Gilman, "Manual de Los Hongos Del Suelo," Compañía Editorial Continental S.A, México D.F., 1963.

[58] G. Smith, "Introducción a la Micología Industrial," Editorial Acribia, España, 1963.

[59] T. Mier, C. Toriello and M. Ulloa, "Hongos Microscópicos Saprobios y Parásitos: Métodos de Laboratorio," UAM-UNAM, México D. F., 2000.

[60] S. S. Radwan, N. A. Sorkhoh, F. Fardoun and R. H. Al-Hasan, "Soil Management Enhancing Hydrocarbon Degradation in the Polluted Kuwaitii Desert," Applied Microbiology and Biotechnology, Vol. 44, No. 1-2, 1995 , pp. 265-270. http://dx.doi.org/10.1007/BF00164513

[61] T. M. April, J. M. Foght and R. S. Currah, "Hydrocarbon-Dagrading Filamentous Fungi. Isolated from Flare
Pit Soils in Northern and Western Canada," Canadian Journal of Microbiology, Vol. 46, No. 1, 2000, pp. 38-49.

[62] G. Nkwelang, F. L. Kamga, E. Nkeng and S. P. Antai, "Studies on the Diversity, Abundance and Succession of Hydrocarbon Utilizing Micro Organisms in Tropical Soil Polluted with Oily Sludge," African Journal of Biotechnology, Vol. 8, 2008, pp. 1075-1080.

[63] K. Jeonge-Dong and L. Choul-Gyun, "Microbial Degradation of Polycyclic Aromatic Hydrocarbons in Soil by Bacterium-Fungus Co-Cultures," Biotechnology and Bioprocess Engineering, Vol. 12, No. 4, 2007, pp. 410-416. http://dx.doi.org/10.1007/BF02931064

[64] O. Obire, E. C. Anyanwu and R. N. Okigbo, "Saprophytic and Crude Oil Degrading Fungi from Cow Dung and Poultry Droppings as Bioremediating Agents," Journal of Agricultural Science and Technology, Vol. 4, 2008, pp. 81-89.

[65] M. A. Hernández-Rivera, M. E. Ojeda-Morales, J. G. Martínez-Vázquez, V. Villegas-Cornelio and Y. CórdovaBautista, "Optimal Parameters for in Vitro Development of the Hydrocarbonoclastic Microorganism Proteus sp.," Journal of Soil Science and Plant Nutrition, Vol. 11, No. 1, 2011, pp. 29-43.

[66] C. C. Okoro, "Biodegradation of Hydrocarbons in Untreated Produce Water Using Pure Fungal Cultures," African Journal of Microbiology Research, Vol. 2, 2008, pp. 217-223.

[67] K. Lee and E. M. Levy, "Biodegradation of Petroleum in the Marine Environment and Its Enhancement," In: J. O. Nriagu and J. S. S. Lakshminarayana, Eds., Aquatic Toxicology and Water Quality Management, John Wiley and Sons Inc., New York, 1989, pp. 217-243.

[68] B. T. Walton, E. A. Guthrie and A. M. Hoylman, "Toxicant Degradation in the Rhizosphere," In: T. A. Anderson, and J. R. Coats, Eds., Bioremediation through Rhizosphere Technology, American Chemical Society, Washington DC, 1994, pp. 11-26. http://dx.doi.org/10.1021/bk-1994-0563.ch002

[69] E. Rosenberg and E. Z. Ron, "Bioremediation of Petroleum Contamination," In: R. L. Crawford and D. L. Crawford, Eds., Bioremediation: Principles and Applications, Cambridge University Press, Cambridge, 1998, pp. 100-124.

[70] J. C. Méndez-Zavala, F. Contreras, R. Lara, R. Victoriano and R. Rodríguez, "Producción Fúngica de un Pigmento Rojo Empleando la Cepa Xerofilica Penicillium purpurogenum GH-2," Revista Mexicana de Ingeniería Quimica, Vol. 6, 2007, pp. 267-273.

[71] Y. J. Cho, J. P. Park, H. J. Hwan, S. W. Kim, J. W. Choi and J. W. Yun, "Production of Red Pigment Bye Submerged Culture of Paecilomyces sinclairii," Letters in Applied Microbiology, Vol. 35, No. 3, 2002, pp. 195-202. http://dx.doi.org/10.1046/j.1472-765X.2002.01168.x

[72] Y. J. Cho, H. J. Hwang, S. N. Kim, C. H. Song and J. W. Yun, "Effect of Carbon Source and Aeration Rate on Broth Rheology and Fungal Morphology during Red Pigment Production by Sinclairii in Batch Bioreactor," Journal of Biotechnology, Vol. 95, No. 1, 2002, pp. 1323. 
[73] M. Alexander, "Biodegradation and Bioremediation," Academic Press, San Diego, 1994.

[74] A. Saraswathy and R. Hallberg, "Mycelial Pellet Formation by Penicillium ochrochloron Species Due to Exposure to Pyrene," Microbiological Research, Vol. 160, No. 4, 2005, pp. 375-383.

http://dx.doi.org/10.1016/j.micres.2005.03.001

[75] J. E. L. Corry, "Relationships of Water Activity to Fungal Growth," In: V. N. Reinhold, Ed., Food and Beverage Micology, Beuchat LR, New York, 1987, pp. 51-99.

[76] J. Lacey, "Pre- and Post-Harvest Ecology of Fungi Causing Spolage of Foods and Other Stored Products," Jour- nal of Applied Bacteriology, Symposium Supplement, 1989, pp. 11S-25S.

[77] E. Ercoli, J. Gálvez, M. Di Paola, J. Cantero, S. Videla, M. Medaura and J. Bauzá, “Análisis y Evaluación de Parámetros Críticos en Biodegradación de Hidrocarburos en Suelo," In: C. Producción III, Ed., Workshop Latinoamericano Sobre Aplicaciones de la Ciencia en la Ingeniería de Petróleo, Formato electrónico, Puerto Iguazú, 2000.

[78] V. Sanchis, F. Lafuente, I. Vinas, M. Torres and R. Canela, "Influence of Incubation Conditions in the Patulin Production by Penicillium griseofulvum Dierckx," Rev. 